Tersedia online di: http://ejournal-balitbang.kkp.go.id/index.php/jra

\title{
PENGGUNAAN TEPUNG DAUN MURBEI (Morus alba L) DALAM PAKAN PEMBESARAN KEPITING BAKAU, Scylla olivacea
}

\author{
Kamaruddin\#, Usman, dan Asda Laining \\ Balai Riset Perikanan Budidaya Air Payau dan Penyuluhan Perikanan \\ (Naskah diterima: 21 November 2017; Revisi final: 9 Januari 2018; Disetujui publikasi: 9 Januari 2018)
}

\begin{abstract}
ABSTRAK
Salah satu bahan nabati yang perlu dievaluasi sebagai bahan pakan untuk kepiting bakau adalah daun murbei yang mengandung protein cukup tinggi dan hormone ecdisterone yang penting untuk proses molting krustase. Tujuan penelitian ini adalah untuk mendapatkan dosis optimum penggunaan tepung daun murbei dalam pakan pembesaran kepiting bakau, Scylla olivacea. Juvenil kepiting bakau yang digunakan terdiri atas 3 kelompok ukuran bobot yaitu (i) $36 \pm 1,9 \mathrm{~g}$; (ii) $45 \pm 1,5 \mathrm{~g}$; dan (iii) $63 \pm 3,9 \mathrm{~g}$. Perlakuan yang dicobakan adalah enam pakan dengan kandungan tepung daun murbei yang berbeda yaitu: 0\%DM 0); $10 \%$ (DM 10); 12,5\%(DM 12,5); 15\%(DM 15); 17,5\%(DM 17,5); dan 20\%(DM20). Wadah penelitian yang digunakan berupa kotak kepiting (crab box) sebanyak 90 buah, diisi sebanyak 1 ekor/boks, dan didisain dengan rancangan acak kelompok. Pemberian pakan uji dilakukan dua kali sehari pukul 08.00 dan pukul 17.00 sebanyak 3-4\% dari biomassa per hari. Hasil penelitian menunjukkan bahwa laju pertumbuhan spesifik (bobot, lebar karapas, dan panjang karapas), serta sintasan kepiting, rasio konversi pakan, dan efisiensi protein pakan, tidak berbeda nyata $(P>0,05)$ antar perlakuan. Namun kandungan tepung daun murbei dalam pakan di atas 15\%menurunkan nilai koefisien kecernaan total pakan, dan kandungan tepung murbei di atas 17,5\% menurunkan nilai kecernaan protein pakan. Berdasarkan respon pertumbuhan dan nilai kecernaan pakan, tepung daun murbei dapat dimanfaatkan hingga 15\%dalam pakan pembesaran kepiting bakau.
\end{abstract}

KATA KUNCl: daun murbei; pakan pembesaran; mud crab; Scylla olivacea

ABSTRACT: The use of mulberry leaf meal (Morus alba L) in grow-out diet for mud crab, Scylla olivacea. By: Kamaruddin, Usman, and Asda Laining

One of plant ingredients suitable to be evaluated as a feed ingredient for mud crab is mulberry leaves which contains protein and ecdisteron. The purpose of this study is to obtain the optimum dose of mulberry leaf meal in grow-out diet for mud crab Scylla olivacea. Juvenile mud crabs were used consisting of 3 groups of weight size ie. (i) $36 \pm 1.9 \mathrm{~g}$; (ii) $45 \pm 1.5 \mathrm{~g}$; and (iii) $63 \pm 3.9 \mathrm{~g}$. The treatments were six diets containing different levels of mulberry leaf at $0 \%(\mathrm{DM} 0)$; 10\%(DM 10); 12,5\%(DM 12,5); 15\%(DM 15); 17,5\%(DM 17,5); and 20\%(DM 20). The experiment was conducted using $90 \mathrm{crab}$ boxes with a density of 1 individual/box. Feeding was applied twice a day at 08.00 and 17.00 with the rate of 3-4\% of biomass per day. The results showed that the specific growth rates (weight, carapace width, and carapace length) and survival rate of crab, feed conversion ratio, and feed protein efficiency were not significantly different $(P>0.05$ ) among the treatments. However, mulberry leaf meal content above $15 \%$ in the diet decreased the apparent digestibility coefficient of dry matter (total) diet, and mulberry leaf meal content above of $17.5 \%$ decreased the apparent digestibility coefficient of protein diets. Based on the growth response and the apparent digestibility coefficient of the test diets, mulberry leaf meal can be utilized up to $15 \%$ in diet for mud crab grow-out.

KEYWORDS: mulberry leaves; grow-out diet; mud crab; Scylla olivacea

\section{PENDAHULUAN}

Dalam pembesaran kepiting bakau, produksi kepiting cangkang lunak, dan penggemukan masih

\footnotetext{
\# Korespondensi: Balai Riset Perikanan Budidaya Air Payau dan Penyuluhan Perikanan. Jl. Makmur Dg. Sitakka No.129, Maros 90512, Sulawesi Selatan, Indonesia.

Tel. + 62411371544

E-mail: dgbilla@yahoo.com
}

menggunakan ikan rucah sebagai pakan utama. Mengingat penggunaan ikan rucah sangat kompetitif dan kualitasnya yang fluktuatif, maka perlu mencari pakan alternatif dalam pemeliharaan kepiting bakau. Saat ini disadari bahwa keberhasilan pengembangan budidaya kepiting bakau ke depan sangat tergantung pada adanya pakan formula yang ekonomis dan bermutu (Fielder, 2004). Beberapa informasi pakan pembesaran kepiting bakau yang telah diperoleh di 
antaranya kebutuhan protein pakan $32-40 \%$ (Chin et al., 1992; Catacutan, 2002), lemak 5,3-13,8\%(Sheen \& Wu, 1999; Catacutan, 2002), energi total 14,7-17,6 $\mathrm{MJ} / \mathrm{kg}$ (Catacutan, 2002), kolesterol 0,51\% (Sheen, 2000), serta kecernaan beberapa bahan hewani dan nabati (Catacutan et al., 2003; Tuan et al., 2006; Truong et al., 2008). Hasil penelitian tersebut menunjukkan bahwa kepiting bakau mampu mencerna bahan-bahan nabati dengan baik, sehingga bahan-bahan tersebut berpotensi digunakan sebagai bahan baku utama yang dapat diramu menjadi pakan yang low-cost effective. Aslamyah \& Fujaya (2010) telah melakukan penelitian dan menghasilkan formulasi berbahan baku limbah dan bahan terestrial yang ramah lingkungan dengan penambahan ekstrak bayam sebagai salah satu sumber ecdisteron (hormon yang berperan dalam proses pemacuan molting krustase untuk tumbuh). Penggunaan hormon dari ekstrak daun murbei untuk menstimulasi molting kepiting bakau juga telah dilakukan oleh Jompa et al. (2013). Penggunaan ekstrak bayam maupun ekstrak daun murbei sulit dilakukan di tingkat pembudidaya karena proses ekstraksinya relatif sulit.

Daun murbei (Morus alba) merupakan makanan pokok bagi ulat sutra (filum Arthropoda) yang sangat dibutuhkan untuk proses ganti kulit, metamorfosis, dan pertumbuhan. Kesamaan filum antara ulat sutra dan kepiting bakau yang juga sangat membutuhkan pergantian kulit (molting) dalam proses pertumbuhannya, diduga daun murbei ini dapat memberi pengaruh positif bagi pergantian kulit dan pertumbuhan kepiting bakau. Daun murbei mengandung ecdisteron sebanyak 1.088,4 ppm (Jompa et al. 2014). Ecdisteroin ini merupakan hormon steroid utama pada serangga dan arthropoda yang memiliki fungsi utama sebagai hormon molting dan juga berperan dalam pengaturan fungsi fisiologis seperti pertumbuhan, metamorfosis, dan reproduksi diduga mekanisme kerjanya juga berlaku pada krustase seperti kepiting bakau. Daun murbei mengandung protein kasar sekitar18,5-23\% lemak kasar 3,62-4,1\% serat kasar 12,5-16,2\% abu 10,6-14,8\% dan BETN 4355\%(Samsijah, 1992; Datta, 2002). Pada daun murbei juga teridentifikasi adanya asam askorbat, karotein, vitamin B1, asam folat dan pro vitamin D (Singh \& Makkar, 2002). Saat ini, pemanfaatan daun murbei masih terbatas sebagai makanan ulat sutra dan makanan ternak ruminansia, sementara potensi produksinya mencapai 20 ton bahan kering/ha/tahun (Syahriani, 2009). Oleh karena itu, daun murbei ini juga berpotensi untuk dimanfaatkan sebagai bahan pakan dalam pembesaran kepiting bakau. Penelitian ini bertujuan untuk mendapatkan dosis optimum penambahan tepung daun murbei dalam pakan dan pengaruhnya terhadap pertumbuhan kepiting bakau (Scylla olivacea).

\section{BAHAN DAN METODE}

Penelitian ini dilakukan dari bulan Juli sampai Okto ber 2016, di Instal asi Tambak Percobaan Maranak, Balai Riset Perikanan Budidaya Air Payau dan Penyuluh Perikanan (BRPBAP3) Maros.

\section{Pakan Uji}

Pakan uji yang digunakan adalah pakan buatan berbentuk pellet dengan perlakuan yang diberikan dibedakan dari persentase tepung daun murbei dalam pakan yaitu: 0\%(DM0); 10\%(DM 10); 12,5\%(DM 12,5); 15\%(DM 15); 17,5\%(DM 17,5); dan 20\%(DM 20). Pakan uji yang diformulasikan tanpa DM (daun murbei) dijadikan sebagai kontrol. DM yang digunakan berupa daun muda yaitu antara daun tua dan daun pucuk, diperoleh dari perkebunan Balai Pensutraan Alam, Kabupaten Gowa Sulawesi Selatan. Daun murbei segar dengan kadar air 94\% dikeringkan dalam oven pada suhu $60^{\circ} \mathrm{C}$ selama 24 jam, kemudian ditepungkan dengan menggunakan hammer mill. Tepung daun murbei kering memiliki kadar protein 20,8\% lemak 3,9\% serat kasar 14,4\% abu 12,7\% dan BETN 48,2\% Komposisi pakan uji selengkapnya disajikan pada Tabel 1 .

\section{Hewan Uji}

Hewan uji yang digunakan adalah juvenil kepiting bakau spesies Scylla olivacea, yang dikelompokkan dalam 3 ukuran yaitu: (i) bobot 36 $\pm 1,9 \mathrm{~g}$; lebar karapas $5,95 \pm 0,20 \mathrm{~cm}$; panjang karapas $3,77 \pm 0,21 \mathrm{~cm}$; (ii) bobot $45 \pm 1,5 \mathrm{~g}$; lebar karapas $5,93 \pm 0,34 \mathrm{~cm}$; panjang

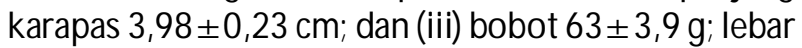

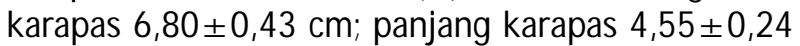
cm; pengelompokan tersebut dilakukan ukuran hewan uji pada saat itu sangat berpariasi. Kepiting bakau dipelihara secara individu menggunakan 90 unit keranjang plastik (crab box) dengan ukuran $20 \mathrm{~cm} \mathrm{x}$ $30 \mathrm{~cm}$ x $30 \mathrm{~cm}$ yang memungkinkan kepiting bebas bergerak di dalamnya. Setiap wadah diisi satu ekor kepiting dan diapungkan di dalam tambak dengan menggunakan bingkai berukuran $1 \mathrm{~m} \times 4 \mathrm{~m}$, yang terbuat dari pipa berdiameter 0,5 dan 1 inch. Setiap perlakuan terdiri atas 15 unit keranjang (individu) yang didesain dengan rancangan acak kelompok berdasarkan ukuran hewan uji. Agar pakan dan sisanya tidak jatuh melalui lubang-lubang pada crab box, maka pada bagian samping dan dasar crab box dipasangkan waring hijau (dengan jahitan). Selama 100 hari pemeliharaan, kepiting diberi pakan uji sebanyak 3-4\%perhari dari bobot kepiting, pada pagi dan petang/malam hari. Untuk perhitungan rasio konversi pakan, sisa pakan diambil sebelum pemberian pakan berikutnya, 
Tabel 1. Formulasi dan komposisi proksimat pakan uji (\%bobot kering)

Table 1. Formulation and proximate composition of tested diets (\%dry weight)

\begin{tabular}{|c|c|c|c|c|c|c|}
\hline \multirow{2}{*}{ Bahan (Ingredients) } & \multicolumn{6}{|c|}{ Pakan uji (Tested feed) } \\
\hline & DM 0 & DM 10 & DM 12.5 & DM15 & DM 17.5 & DM20 \\
\hline Tepung ikan lokal (Local fish meal) & 40 & 40 & 40 & 40 & 40 & 40 \\
\hline Tepung cangkang kepiting (Crab shell meal) & 10 & 10 & 10 & 10 & 10 & 10 \\
\hline Bungkil kopra (Copra cake meal) & 8 & 6 & 5 & 4 & 3 & 2 \\
\hline Tepung jagung (Corn flour) & 12 & 10 & 9 & 8 & 7 & 6 \\
\hline Tepung kedele (Soybean flour ) & 18 & 15 & 14.5 & 14 & 13.5 & 13 \\
\hline Tepung terigu (Wheat flour) & 10 & 7 & 7 & 7 & 7 & 7 \\
\hline Tepung daun murbei (Mulberry leaf meal ) & 0 & 10 & 12.5 & 15 & 17.5 & 20 \\
\hline Vitamin dan mineral premix (Vitamin and mineral premix ) & 2 & 2 & 2 & 2 & 2 & 2 \\
\hline \multicolumn{7}{|l|}{ Komposisi proksimat (Proximate composition ) } \\
\hline - Protein kasar (Crude Protein ) & 33.4 & 35 & 35.1 & 35.1 & 35.1 & 34.7 \\
\hline - Lemak (Lipid) & 8.7 & 8.3 & 8.1 & 8 & 7.8 & 7.7 \\
\hline - Serat kasar (Crude fibre) & 2.6 & 3.9 & 4.2 & 4.5 & 4.8 & 5.1 \\
\hline - Abu (Ash) & 11.1 & 12 & 12.3 & 12.5 & 12.8 & 13.1 \\
\hline - BETN / NFE ${ }^{1)}$ & 44.2 & 40.8 & 40.3 & 39.9 & 39.5 & 39.4 \\
\hline - Energi total $(\mathrm{MJ} / \mathrm{kg}) /$ Gross energy $(\mathrm{MJ} / \mathrm{kg}) 2$ ) & 18.2 & 17.7 & 17.6 & 17.5 & 17.3 & 17.2 \\
\hline
\end{tabular}

selanjutnya dikeringkan dan ditimbang, karena tidak selamanya pakan yang diberikan pada saat itu dihabiskan Sampling pertumbuhan dilakukan setiap 10 hari. Pergantian air tambak dilakukan secara periodik berdasarkan siklus pasang surut.

\section{Uji Kecernaan Pakan}

Pengamatan kecernaan pakan dilakukan dengan menggunakan wadah percobaan 12 unit tanki fibre glass berukuran $40 \mathrm{~cm} \times 60 \mathrm{~cm} \times 50 \mathrm{~cm}$ yang disekat menjadi 6 bagian, dan dilengkapi dengan sistem aerasi. Setiap sekatan dalam bak diisi hewan uji sebanyak 1 ekor, dengan bobot rata-rata $50 \pm 1,5 \mathrm{~g} /$ ekor dan masing-masing perlakuan terdiri atas 2 ulangan. Pakan uji yang digunakan ditambahkan kromium oksida $\left(\mathrm{Cr}_{2} \mathrm{O}_{3}\right)$ sebagai indikator masingmasing sebanyak $0,7 \%$ pada setiap formulasi pakan (Takeuchi, 1988). Kepiting bakau diberi pakan uji sebanyak 3\%bobot badan per hari dengan frekuensi dua kali sehari pada pagi dan sore hari. Beberapa saat setelah pemberian pakan, dilakukan pengambilan sisa pakan. Sebelum pengambilan feses dimulai, hewan uji diadaptasikan terlebih dahulu dengan pakan uji tersebut selama satu minggu, setelah itu baru dilakukan pengumpulan feses setiap 3 jam untuk menghindari terjadinya leaching nutrien pada feses. Feses yang terkumpul secepatnya disimpan dalam freezer hingga cukup untuk dikeringkan dan dianalisis di laboratorium. Untuk mempertahankan mutu air agar selalu dalam kondisi yang layak bagi kehidupan hewan uji, maka dilakukan pergantian sebanyak $80 \%$ per hari.

\section{Analisa Data dan Sampel}

Untuk melihat kinerja pertumbuhan dan pemanfaatan pakan uji, beberapa peubah yang diamati dan dihitung yaitu:

(1) Laju pertumbuhan spesifik (SGR) terhadap bobot tubuh, lebar karapas dan panjang karapas kepiting yang dihitung dengan formula (Schulz et al., 2005):

$$
\text { SGR (\%per hari) }=100 \times\left(\frac{\ln W \mathrm{t}-\operatorname{InW}}{\mathrm{t}}\right)
$$

di mana:

In : logaritma alamiah

Wt : bo bot akhir, lebar karapas akhir, atau panjang karapas akhir

Wo : bobot awal, lebar karapas awal, atau panjang karapas awal

t : lama (hari) pemeliharaan

(2) Rasio konversi pakan (FCR) dihitung berdasarkan Unnikrishnan \& Paulraj (2010):

$$
\mathrm{FCR}=\frac{\text { Jumlah pakan yang diberikan }(\mathrm{g})}{(\text { Pertambahan bobot ikan uji) }(\mathrm{g})}
$$


(3) Rasio efisiensi protein (REP) ditentukan mengikuti Mohseni \& Ozorio (2014):

$$
\mathrm{REP}=\frac{\text { Pertambahan bobot hewan uji (g) }}{\text { Jumlah protein yang dimakan (g) }}
$$

(4) Sintasan (SR):

$$
\text { SR }(\%)=\frac{\text { Jumlah hewan uji di akhir penelitian }}{\text { Jumlah hewan uji di awal penelitian }} \times 100 \%
$$

(5) Koefisien kecernaan (AD) berat kering (DM), protein kasar (CP), dan BETN pakan (E) dihitung berdasarkan rumus (Takeuchi, 1988; Hardy, 1989):

$$
A D(\%)=100 *\left\{1-\left(\frac{M_{D} * A_{F}}{M_{F} * A_{D}}\right)\right\}
$$

di mana:

$M_{D}$ dan $M_{F}$ berturut-turut adalah konsentrasi indikator $\mathrm{Cr}_{2} \mathrm{O}_{3}$ (\%bobot kering) dalam pakan dan feses

$A_{D}$ dan $A_{F}$ adalah konsentrasi nutrient (\%bobot kering) dalam pakan dan feses

Analisis proksimat pakan dan kepiting mengacu AOAC (1999) terhadap sampel yang representatif. Kandungan bahan kering sampel diperolah dengan mengeringkannya dalam oven pada suhu $105^{\circ} \mathrm{C}$ selama 16 jam, protein kasar dianalisis dengan microKjeldahl, dan lemak dideterminasi secara grafimetrik dengan extraksi chloroform: methanol. Serat kasar dianalisis dengan pemanasan yang disertai pencucian asam dan basa secara bergantian, dan abu dengan pembakaran dalam tanur pada suhu $550^{\circ} \mathrm{C}$ selama 24 jam.

Peubah pemanfaatan pakan uji, kinerja pertumbuhan kepiting dan kecernaan pakan dianalisis ragam dan uji lanjut dengan uji Beda Nyata Terkecil (BNT) (Steel \& Torrie, 1995), sementara nilai kualitas air dianalisis secara deskriptif.

\section{HASIL DAN BAHASAN}

Performansi pertumbuhan juvenil kepiting bakau yang diberi pakan dengan jumlah kandungan tepung daun murbei berbeda dalam pakan disajikan pada Tabel 2. Berdasarkan hasil anal isis ragam menunjukkan hasil tidak berbeda $(P>0,05)$ terhadap performansi pertumbuhan, nilai kecernaan pakan, laju pertumbuhan spesifik (bobot, lebar, dan panjang karapas) dan sintasan kepiting bakau setelah pemeliharaan selama 100 hari pemeliharaan. Hal ini diduga karena persentase molting kepiting selama penelitian cukup rendah untuk semua perlakuan hanya $40 \%$ Seperti yang dilaporkan oleh Kim et al. (2000) bahwa murbei mengandung banyak senyawa kimia salah satunya adalah ecdysterone yang merupakan jenis hormon yang berperan dalam memicu molting crustaceae. Meskipun pemanfaatan tepung daun murbei $20 \%$ dalam formulasi pakan pembesaran kepiting bakau belum bisa memberikan rangsangan terhadap kepiting untuk molting, akan tetapi bisa berfungsi sebagai sumber karbohidrat dan protein pengganti bungkil kopra, tepung jagung, dan bersama tepung kedele seperti dalam formulasi pakan uji ini (Tabel 1).

Jompa et al. (2010) melaporkan bahwa pertumbuhan bobot dan lebar karapas kepiting bakau tertinggi dijumpai pada kombinasi pellet dengan ikan rucah, namun berbeda dengan hanya menggunakan pakan pelet udang saja. Sedangkan Trino et al. (2001) melaporkan bahwa laju pertumbuhan spesifik dari beberapa jenis kepiting bakau yang diberi pakan berupa pelet dapat menyamai pemberian pakan ikan rucah.

Salah satu peubah yang sering digunakan dalam menilai tingkat pemanfaatan pakan adalah rasio konversi pakan. Pada Tabel 2 terlihat bahwa rasio konversi pakan relatif sama $(P>0,05)$ antar perlakuan (Tabel 2). Nilai rasio konversi pakan yang didapatkan pada penelitian ini relatif lebih rendah dibangdingkan dengan hasil penelitian Qomariyah et al. (2014) yaitu 3,37-8,08 pada kepiting bakau (S. paramamosain) dengan perlakuan persentase pakan yang berbeda, meskipun relatif sama yang didapatkan oleh Catacutan (2002) yaitu 3,3-4,21. Namun secara umum, aplikasi pakan buatan dalam pembesaran kepiting bakau ini masih memiliki nilai konversi pakan yang tinggi $(>2,5)$. Ini menunjukkan bahwa pakan buatan yang diberikan masih belum dimanfaatkan secara optimal. Sifat kepiting bakau yang memegang pakan menggunakan capitnya dan mencabik-cabik pakan saat dimasukkan dalam mulutnya menyebabkan banyak bagian pakan yang hancur terutama jika diberikan dalam bentuk pelet kering.

Pada rasio efisiensi protein pakan juga tidak ditemukan adanya perbedaan yang nyata $(P>0,05)$ antar perlakuan (Tabel 2). Hal ini menunjukkan bahwa pemanfaatan protein pakan untuk pertumbuhan kepiting bakau tersebut memiliki proporsi yang relatif sama antar perlakuan. Efisien protein dalam penelitian ini lebih tinggi dibandingkan hasil penelitian yang diperoleh Qomariyah et al. (2014) yaitu 0,11-0,25 pada kepiting bakau (S. paramamosain).

Komposisi proksimat kepiting bakau setelah 100 hari pemberian pakan uji disajikan pada Tabel 3. Pada Tabel 3 tersebut terlihat bahwa kandungan protein, lemak, abu, serat kasar, dan bahan ekstrak tanpa nitrogen (BETN) tidak berbeda nyata $(P>0,05)$ antar perlakuan. Hal ini menunjukkan bahwa komposisi 
Tabel 2. Performansi pertumbuhan kepiting bakau dan pemanfaatan pakan uji yang mengandung jumlah tepung daun murbei yang berbeda dalam pakan

Table 2. Growth performance of mud crab and utilization of tested diets containing different levels of mulberry leaf meal

\begin{tabular}{|c|c|c|c|c|c|c|}
\hline \multirow{2}{*}{ Peubah (Variables) } & \multicolumn{6}{|c|}{ Pakan uji (Test diets) } \\
\hline & DM 0 & DM10 & DM12.5 & DM15 & DM17.5 & DM20 \\
\hline $\begin{array}{l}\text { Rata-rata bobot awal } \\
\text { Average initial weight ( } \mathrm{g} \text { /ind) }\end{array}$ & 47.2 & 49 & 47.2 & 49.2 & 47.9 & 47.4 \\
\hline $\begin{array}{l}\text { Lebar karapas awal rata-rata } \\
\text { Average initial carapace width }(\mathrm{cm})\end{array}$ & 6.1 & 6.1 & 6 & 6.2 & 6.2 & 6.1 \\
\hline $\begin{array}{l}\text { Rata-rata panjang karapas awal } \\
\text { Average initial carapace length }(\mathrm{cm})\end{array}$ & 4.1 & 4.1 & 4 & 4.2 & 4.2 & 4 \\
\hline $\begin{array}{l}\text { Rata-rata bobot akhir } \\
\text { Average final body weight (g/ ind) }\end{array}$ & $80.3 \pm 17.5^{\mathrm{a}}$ & $92.6 \pm 38.3^{a}$ & $86.9 \pm 16.7^{\mathrm{a}}$ & $84.2 \pm 27.8^{\mathrm{a}}$ & $82.4 \pm 21.9^{\mathrm{a}}$ & $83.3 \pm 8.2^{\mathrm{a}}$ \\
\hline $\begin{array}{l}\text { Rata-rata lebar karapas akhir } \\
\text { Average final carapace width (cm) }\end{array}$ & $7.0 \pm 0.5^{\mathrm{a}}$ & $7.0 \pm 0.6^{a}$ & $7.1 \pm 0.4^{a}$ & $7.0 \pm 0.9^{a}$ & $7.2 \pm 0.6^{\mathrm{a}}$ & $7.0 \pm 0.4^{\mathrm{a}}$ \\
\hline $\begin{array}{l}\text { Rata-rata panjang karapas akhir } \\
\text { Average initial carapace length }(\mathrm{cm})\end{array}$ & $5.0 \pm 0.5^{\mathrm{a}}$ & $5.0 \pm 0.7^{\mathrm{a}}$ & $5.0 \pm 0.3^{a}$ & $5.1 \pm 0.7^{\mathrm{a}}$ & $5.0 \pm 0.3^{a}$ & $5.0 \pm 0.4^{\mathrm{a}}$ \\
\hline $\begin{array}{l}\text { Laju pertumbuhan bobot spesifik (\%hari) } \\
\text { Specific growth rate of body weight (\%day) }\end{array}$ & $0.56 \pm 0.13^{\mathrm{a}}$ & $0.63 \pm 0.06^{a}$ & $0.62 \pm 0.07^{\mathrm{a}}$ & $0.53 \pm 0.03^{\mathrm{a}}$ & $0.54 \pm 0.05^{\mathrm{a}}$ & $0.58 \pm 0.16^{\mathrm{a}}$ \\
\hline $\begin{array}{l}\text { Laju pertumbuhan lebar karapas spesifik (\%hari) } \\
\text { Specific growth rate of carapace widtht (\%/day) }\end{array}$ & $0.15 \pm 0,03^{\mathrm{a}}$ & $0.18 \pm 0.03^{\mathrm{a}}$ & $0.17 \pm 0.05^{\mathrm{a}}$ & $0,16 \pm 0.03^{\mathrm{a}}$ & $0.17 \pm 0.07^{\mathrm{a}}$ & $0.14 \pm 0.04^{\mathrm{a}}$ \\
\hline $\begin{array}{l}\text { Laju pertumbuhan panjang karapas spesifik (\%/hari) } \\
\text { Spedific growth rate of carapace length (\%/day) }\end{array}$ & $0.20 \pm 0.01^{\mathrm{a}}$ & $0.20 \pm 0.03^{\mathrm{a}}$ & $0.21 \pm 0.04^{\mathrm{a}}$ & $0.18 \pm 0.05^{\mathrm{a}}$ & $0.18 \pm 0.04^{\mathrm{a}}$ & $0.23 \pm 0.05^{\mathrm{a}}$ \\
\hline $\begin{array}{l}\text { Sintasan } \\
\text { Survival rate }(\%)\end{array}$ & $86.7 \pm 11.5^{\mathrm{a}}$ & $86.7 \pm 11.5^{\mathrm{a}}$ & $80.0 \pm 20.0^{\mathrm{a}}$ & $80.0 \pm 20.0^{a}$ & $80.0 \pm 20.0^{a}$ & $80.0 \pm 20.0^{\mathrm{a}}$ \\
\hline $\begin{array}{l}\text { Rasio konversi pakan } \\
\text { Feed Conversion Ratio }\end{array}$ & $4.16 \pm 0.16^{\mathrm{a}}$ & $3.96 \pm 1.62^{\mathrm{a}}$ & $4.42 \pm 0.82^{\mathrm{a}}$ & $4.77 \pm 1.8^{\mathrm{a}}$ & $4.53 \pm 1.32^{\mathrm{a}}$ & $4.42 \pm 1.04^{\mathrm{a}}$ \\
\hline $\begin{array}{l}\text { Rasio efisiensi protein } \\
\text { Protein efficiency ratio }\end{array}$ & $0.7 \pm 0.03^{\mathrm{a}}$ & $0.84 \pm 0.45^{\mathrm{a}}$ & $0.66 \pm 0.12^{\mathrm{a}}$ & $0.66 \pm 0.24^{\mathrm{a}}$ & $0.66 \pm 0.19^{\mathrm{a}}$ & $0.67 \pm 0.14^{\mathrm{a}}$ \\
\hline
\end{tabular}

proksimat tubuh kepiting bakau tidak mengalami perubahan akibat penggunaan tepung daun murbei dalam pakan mulai dari 0 hingga 20\% Namun secara umum, kandungan protein kasar dan lemak total tubuh kepiting bakau yang didapatkan pada penelitian ini cenderung lebih rendah daripada yang didapatkan oleh Aslamyah \& Fujaya (2010) dengan kandungan protein 37,2-38,0\%dan lemak 6,3-8,1\%pada perlakuan kadar protein dan karbohidrat pakan yang berbeda dan salah satu pakan perlakuannya memiliki kandungan protein dan karbohidrat (energi) yang relatif sama dangan pakan uji pada penelitian ini. Sementara kandungan serat kasar dan abu dari tubuh kepiting yang didapatkan pada penelitian ini lebih tinggi daripada yang didapatkan oleh Aslamyah \& Fujaya (2010) yaitu serat kasar 24,7-32,7\%dan kadar abu 10,8-12,5\% Hal ini disebabkan karena jenis bahan baku pakan, formulasi pakan dan ukuran kepiting yang digunakan

Tabel 3. Komposisi proksimat (\%bobot kering) kepiting bakau dengan pemberian pakan yang mengandung jumlah tepung daun murbei berbeda

Table 3. Proximate composition (\%dry weight) of mud crab fed tested diets containing different levels of mulberry leaf meal

\begin{tabular}{lcccccc}
\hline \multirow{2}{*}{ Nutrien (Nutrients) } & \multicolumn{5}{c}{ Pakan uji (Feed test) } \\
\cline { 2 - 7 } & DM 0 & DM 10 & DM 12.5 & DM 15 & DM 17.5 & DM 20 \\
\hline Protein kasar (Crude protein) & $32.0 \pm 2.9^{\mathrm{a}}$ & $31.5 \pm 2.2^{\mathrm{a}}$ & $32.2 \pm 2.7^{\mathrm{a}}$ & $32.1 \pm 1.3^{\mathrm{a}}$ & $32.3 \pm 2.7^{\mathrm{a}}$ & $31.1 \pm 3.5^{\mathrm{a}}$ \\
Lemak kasar (Crude lipid) & $2.7 \pm 0.9^{\mathrm{a}}$ & $3.1 \pm 0.3^{\mathrm{a}}$ & $2.9 \pm 0.4^{\mathrm{a}}$ & $2.8 \pm 0.6^{\mathrm{a}}$ & $2.9 \pm 0.4^{\mathrm{a}}$ & $2.9 \pm 0.6^{\mathrm{a}}$ \\
Serat kasar (Crude fibre) & $14.1 \pm 2.3^{\mathrm{a}}$ & $14.1 \pm 1.7^{\mathrm{a}}$ & $13.2 \pm 1.6^{\mathrm{a}}$ & $14.2 \pm 2.0^{\mathrm{a}}$ & $13.8 \pm 2.1^{\mathrm{a}}$ & $14.0 \pm 2.3^{\mathrm{a}}$ \\
Abu (Ash) & $38.4 \pm 0.6^{\mathrm{a}}$ & $38.1 \pm 2.2^{\mathrm{a}}$ & $38.7 \pm 0.9^{\mathrm{a}}$ & $38.6 \pm 1.0^{\mathrm{a}}$ & $38.9 \pm 1.5^{\mathrm{a}}$ & $39.2 \pm 1.1^{\mathrm{a}}$ \\
BETN (NFE) & $12.8 \pm 5.5^{\mathrm{a}}$ & $13.2 \pm 21.5^{\mathrm{a}}$ & $13.1 \pm 3.2^{\mathrm{a}}$ & $12.4 \pm 1.3^{\mathrm{a}}$ & $12.2 \pm 4.3^{\mathrm{a}}$ & $12.7 \pm 4.1^{\mathrm{a}}$ \\
\hline
\end{tabular}




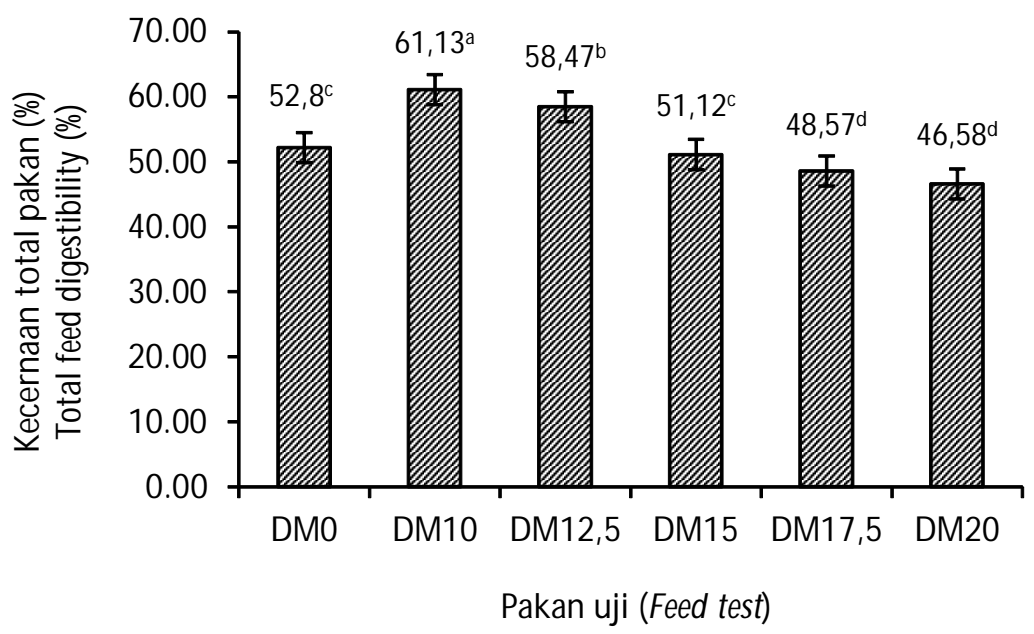

Gambar 1. Koefisien kecernaan total (bahan kering) pakan kepiting bakau yang diberi pakan dengan kandungan daun murbei yang berbeda.

Figure 1. Total (dry matter) digestibility coefficient of diets containing different levels of mulberry leaf meal for mud crab juvenile.

tidak sama yang digunakan oleh Aslamyah \& Fujaya (2010). Salah satu juga faktor yang diduga menyebabkan hewan uji relatif kurus pada akhir penelitian adalah kondisi lingkungan budidaya khususya salinitas air yang cukup tinggi hingga mencapai 44 ppt. Pada kondisi tersebut nafsu makan kepiting cenderung menurun, sementara kebutuhan nutrient untuk metabolisme dasarnya meningkat untuk kebutuhan konpensasi terhadap kondisi lingkungan yang ekstrim. Menurut Shelley \& Lovatelli (2011), pembesaran kepiting bakau tumbuh secara optimum pada salinitas 15-25 ppt dan pada salinitas di atas 35 ppt sudah menghambat pertumbuhannya.

Nilai koefisien kecernaan total pakan tertinggi diperoleh pada perlakuan DM 10 yaitu $61,13 \%$ berbeda nyata $(P<0,05)$ dengan perlakuan lainnya, perlakuan DM $12,5(58,47 \%$ yang juga berbeda nyata $(P<0,05)$ dengan perlakuan lainnya (Gambar 1). Sementara nilai koefisien kecernaan total pakan pada perlakuan DM 15 yaitu $51,12 \%$ tidak berbeda nyata $(P>0,05)$ dengan perlakuan kontrol DM $0(52,80 \%)$ tetapi berbeda nyata $(P<0,05)$ dan lebih tinggi daripada perlakuan DM 17,5 $(48,57 \%)$ dan DM20 $(46,58 \%$. Hal ini menujukkan bahwa penambahan tepung daun murbei lebih dari $15,0 \%$ dalam pakan dapat menurunkan nilai koefisien kecernaaan totalnya pada juvenil kepiting bakau. Penurunan nilai koefisien kecernaan total pakan dengan meningkatnya kandungan tepung daun murbei lebih dari 15\% diduga disebabkan oleh semakin meningkatnya kandungan serat kasar yaitu $\geq 4,8 \%$ dalam pakan (Tabel 1). Sementara penyebab koefisien kecernaan total yang lebih tinggi pada pakan yang mengandung 10-12,5\%daun murbei daripada pakan yang tidak mengandung tepung daun murbei (pakan kontrol) masih perlu pengamatan lebih lanjut.

Nilai koefisien kecernaan protein pakan tertinggi diperoleh pada perlakuan DM10, DM 12,5 dan DM 15 berturut-turut $67,66 \%, 66,66 \%$ dan $66,35 \%$ ketiganya tidak berbeda $(P>0,05)$, namun berbeda nyata $(\mathrm{P}<0,05)$ dengan perlakuan DM 0; DM 17,5; dan DM 20 (Gambar 2). Penambahan tepung daun murbei di atas 15\% dalam pakan dapat menurunkan kecernaan protein pakan, meskipun jumlah protein dalam pakan tersebut relatif sama. Hasil penelitan ini sedikit berbeda dengan yang dilaporkan oleh Tillman et al. (2005) bahwa kecernaan protein kasar tegantung pada kandungan protein pakan, tinggi rendahnya kecernaan protein tergantung pada kandungan protein bahan pakan dan banyaknya protein yang masuk dalam saluran pencernaan. Hal ini disebabkan karena jenis organisme dan jenis pakannya juga berbeda di mana penambahan kandungan daun murbei di atas 15\% dapat meningkatkan kandungan serat kasar, dengan demikian secara langsung dapat memengaruhi kecernaan total (Gambar 1) dan kecernaan protein pakan (Gambar 2). Hertrampf \& Piedad-Pascual (2000) serta Glencross et al. (2012) melaporkan bahwa tingkat pemanfaatan protein bagi pertumbuhan ikan dapat disebabkan oleh dua faktor utama yaitu tingkat kecernaan pakan yang dapat diakibatkan oleh kandungan serat kasar yang tinggi dalam pakan dan kualitas protein pakan (keseimbangan komposisi asam 


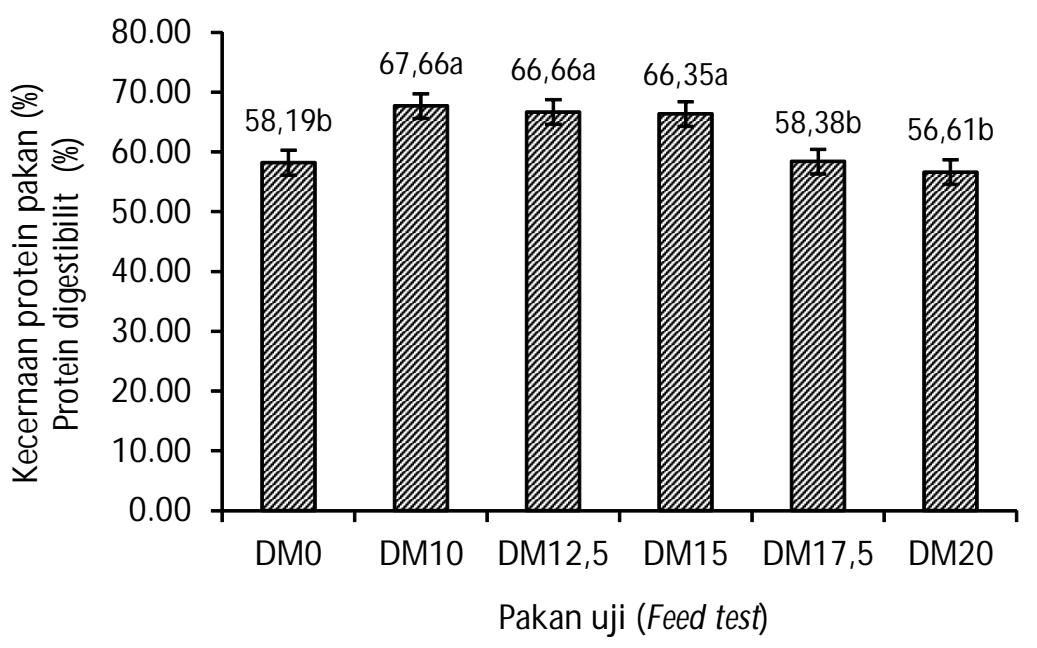

Gambar 2. Koefisiensi kecernaan protein pakan kepiting bakau yang mengandung daun murbei berbeda.

Figure 2. Protein digestibility coefficient of tested diets containing different levels of mulberry leaf meal for mud crab juvenile.

amino essensial). Meningkatnya kandungan serat kasar dalam pakan dapat menyebabkan nilai kecernaan protein menjadi rendah.

Kondisi kualitas air yang diperoleh selama penelitian dinilai masih layak untuk kehidupan dan pertumbuhan kepiting bakau, kecuali parameter salinitas yang meningkat di musim kemarau. Salinitas mengalami peningkatan dari $20 \mathrm{ppt}$ menjadi $44 \mathrm{ppt}$ di akhir penelitian, kondisi salinitas yang cukup tinggi terjadi pada bulan September sampai Oktober (akhir penelitian) yaitu 30-44 ppt. Sementara kandungan oksigen terlarut selama penelitian berlangsung berkisar antara 2,35-4,72 mg/L. Kondisi oksigen pada awal penelitian cukup rendah terutama pada pagi hari. Untuk antisipasi penurunan oksigen terlarut, maka dipasang aerasi dengan menggunakan blower yang dijalankan pagi hari sampai pukul 10 pagi. Fluktuasi salinitas dan oksigen yang cukup tinggi secara langsung memengaruhi nafsu makan kepiting bakau sehingga berdampak pada pertumbuhan menjadi lambat. Seperti yang dilaporkan oleh Saputra et al. (2011) bahwa kisaran salinitas yang optimal untuk pertumbuhan kepiting bakau (S. paramamosain) yaitu 28-30 ppt, sedangkan untuk kebutuhan optimal oksigen terlarut $>4 \mathrm{mg} / \mathrm{L}$. Parameter kualitas air lainnya seperti suhu, pH, dan alkalinitas masih pada batas yang optimal untuk pertumbuhan kepiting bakau. Seperti yang dilaporkan oleh Saputra et al. (2011) bahwa pada pemeliharaan kepiting bakau (S. paramamosain) dapat memberikan pertumbuhan yang baik pada suhu $28,5-30,5^{\circ} \mathrm{C}$; pH 7,5-8,5; alkalinitas $120,2-158,3 \mathrm{mg} / \mathrm{L}$.

\section{KESIMPULAN DAN SARAN}

Berdasarkan respons pertumbuhan dan nilai kecernaan pakan yang diperoleh pada penelitian ini, tepung daun murbei dapat dimanfaatkan hingga 15\% dalam pakan pembesaran kepiting bakau. Penggunaan daun murbei lebih dari 15\%dapat menurunkan nilai kecernaan total pakan dan penambahan tepung daun murbei di atas 17,5\%dapat menurunkan nilai kecernaan protein pakan.

\section{DAFTAR ACUAN}

AOAC International. (1999). Official Methods of Analysis, $16^{\text {th }}$ edn. Association of Official Analytical Chemists International, Gaithersbeg, Maryland, USA, $1141 \mathrm{pp}$.

Aslamyah, S. \& Fujaya, Y. (2010). Stimulasi molting dan pertumbuhan kepiting bakau (Scylla sp.) melalui aplikasi pakan buatan berbahan dasar limbah pangan yang diperkaya dengan ekstrak bayam. IImu Kelautan (Indonesian Journal of M arineScience), 15(3), 170-178.

Catacutan, M.R. (2002). Growth and body composition of juvenile mud crab, Scylla serrata, fed different dietary protein and lipid levels and protein to energy ratios. Aquaculture, 208, 113-123.

Catacutan, M.R., Eusebio, P.S., \& Teshima, S. (2003). Apparent digestibility of selected feedstuffs by mud crab, Scylla serrata. Aquaculture, 216, 253-261.

Chin, H.C., Gunasekera, U.P.D., \& Amandokoon, H.P. (1992). Formulation of artificial feeds for mud crab culture: a preliminary biochemical, physical and 
biological evaluation. In: Angell, C.A. (Ed.), Report of the Seminar on the Mud Crab Culture and Trade, Thailand, 5-8 November 1991. Bay of Bengal Programme for Fisheries Development, Madras, India, $246 \mathrm{pp}$.

Datta, R.K. (2002). Mulberry cultivation and utilization in India. In: Mulberry for Animal Production. SANCHEZ,M.D. (Ed.). FAO Animal Production and Health Paper. No. 147. Rome, Italy, p. 45-62.

Fielder, D. (2004). Crab aquaculture scoping study and workshop. In: Mud Crab Aquaculture in Australia and Southeast Asia. Proceedings of the ACIAR Crab Aquaculture Scoping Study and Workshop, 28-29 April, Joodooburri Conference Centre, Bribie Island. ACIAR Working Paper No. 54 (eds. ByG. Allan $\&$ D. Fielder), p. 10-30. Australian Centre for International Agricultural Research, Canberra, Australia.

Glencross, B., Blyth, D., Tabrett, S., Bourne, N., Irvin, S., Anderson, M., Fox-Smith, \& Smuller, R. (2012). An assessment of grains and other starch sources in diets for barramundi (Lates calcarifer)-implications for nutritional and functional qualities of extruded feeds. Aquaculture Nutrition, 18, 388-399.

Hardy, R.W. (1989). Diet preparation. In Halver, J.E. (ed.). Fish Nutrition. Second Edition. Academic Press, Inc. San Diego, p, 476-549.

Hertrampf, J.W. \& Piedad-Pascual, P. (2000). Handbook on ingredient for aquaculture feeds. Kluwer Academic Publishers, 573 pp.

Jompa, H., Kamaruddin, \& Septianingsih, E. (2013). Efektivitas hormon ecdisterone daun murbei dalam pakan sebagai pemicu molting pada produksi kepiting cangkang lunak. Prosiding Seminar Insentif Riset. SINas (INSINAS 2013). Jakarta 7-8 November 2013. "Membangun Sinergi Riset Nasional untuk Kemandirian Teknologi" Asisten Deputi Relevansi Program Riset IPTEK. Deputi Bidang Relevansi dan Produktivitas IPTEK. Kementrian Riset dan Teknologi. ISBN: 978-602-18926-6-4, hlm. 503-515.

Jompa, H., Sulaeman, \& Tenriulo, A. (2010). Pembesaran kepiting bakau (Scylla serrata) di tambak dengan pemberian pakan berbeda. Prosiding Forum Inovasi Teknologi Akuakultur 2010.

Jompa, H., Tenriulo, A., \& Suryati E. (2014). Hormon ecdyateron dari ekstrak daun murbei, Morus spp., sebagai moulting stimulant pada kepiting bakau. Jurnal Riset Akuakultur, 9(3), 387-397.

Kim, S.Y., Gao J.J., \& Kang H.K. (2000). Two flavonoids from the leaves of Morus alba, induce differentiation of the human promyelocytic leukemia (HL$60)$ cell line, Biol. Pharn Bull., 23(4), 451-456.
Mohseni, M. \& Ozorio, R.O.A. (2014). Effects of dietary L-carnitine level on growth performance, body composition and antioxidant status in beluga (Huso huso L. 1758). Aquaculture Nutrition, 20, 477-485.

Qomariyah, L., Samidjan, I., \& Rachmawati, D. (2014). Pengaruh persentase jumlah pakan buatan yang berbeda terhadap pertumbuhan dan kelulusan hidup kepiting bakau (Scylla paramamosain). Journal of Aquaculture M anagement and Technology, 3(4), 18-25.

Samsijah. (1992). Pemilihan tanaman murbei (morus alba I) yang sesuai dengan daerah Siding Resmi Sukabumi, Jawa Barat. Bul Penelitian Hutan, 547: 45-59.

Saputra, Nuh, S.M.I., \& Yusnaini. (2011). Sintasan dan pertumbuhan larva kepiting bakau (Scylla paramamosain) zoea 2 sampai zoea 5, melalui pemberian jenis bakteri probiotik yang berbeda. Jurnal Mina Laut Indonesia, 3, 81-93.

Schulz, C., Knaus, M., Wirth, M., \& Rennert, B. (2005). Effect of varying dietary fatty acid propile on growth performance, fatty acid, body and tissue composition of juvenile pike perch (Sander lucioperca). Aquaculture Nutrition, 11, 403-413.

Sheen, S.S. (2000). Dietary cholesterol requirement of juvenile mudcrab Scylla serrata. Aquaculture,189, 277-285.

Sheen, S.S. \& Wu, S.W. (1999). The effect of dietary lipid levels on the growth response of juvenile mud crab, Scylla serrata. Aquaculture, 175, 143-153.

Shelley, C. \& Lovatelli, A. (2011). Mud crab aquaculture-A practical manual. FAO Fisheries and Aquaculture Technical Paper. No. 567. Rome, FAO, 78 pp.

Singh, B. \& Makkar, H.P.S. (2002). The potential of mulberry foliage as a feed supplement in India. In: Mulberry for Animal Production. SANCHEZ, M.D.(Ed.). Animal Production and Health Paper, No. 147. FAO Rome, Italy, p. 139-155.

Stell, R.G.D. \& Torry, J.H. (1995). Prinsif dan prosedur statistika. Alih bahasa: Bambang Sumantri. Gramedia Pustaka Utama, Jakarta, $748 \mathrm{hlm}$.

Syahriani, S. (2009). Potensi daun murbei dalam meningkatkan nilai guna jerami padi sebagai pakan sapi potong. Disertasi Doktor. Sekolah Pascasarjana, Institut Pertanian Bogor, Bogor.

Takeuchi, T. (1988). Laboratory work-chemical evaluation of dietary nutrient. In: Watanabe, T. (Ed.). Fish Nutrition and Mariculture. Department of Aquatic Bioscience, Tokyo University of Fisheries, p. 179-233. 
Tillman, A.D., Reksohadiprodjo, S., Prawirokusumo, S., \& Lebdosoekojo, S. (2005). IImu Makanan Ternak Dasar. Gadjah Mada University Prees, Yogyakarta.

Trino, A.T., Millamena, O.M., \& Keenan, C. (1999). Commercial evaluation of monosex pond culture of the mud crab Scylla species at three stocking densities in the Philippines. Aquaculture, 174, 109-118.

Trino, A.T., Millamena, O.M., \& Keenan, C.P. (2001). Pond Culture of Mud Crab (Scylla serrata (Forskal). Fed Formulated Diet with or without Vitamin and mineral Suplements. Proceedings of The International Forum an the Culture of Portunid Crabs. Asian Fisheries Society. Manila, Philippines. Asian Fisheries Science, 14, 191-200.
Truong, P.H., Anderson, A.J., Mather, P.B., Paterson, B.D., \& Richarson, N.A. (2008). Effect of selected feed meals and starches on diet digestibility in the mud crab, Scylla serrata. Aquaculture Research, 39, 1778-1786.

Tuan, V., Anderson, A., Luang-van, J., Shelley, C., \& Allan, G. (2006). Apparent digestibility of some nutrient sources byjuvenile mud crab, Scylla serrata (Forskal 1775). Aquaculture Research, 37, 359-365.

Unnikrishnan, U. \& Paulraj, R. (2010). Dietary protein requirements of giant mud crab Scylla serrata juveniles fed isoenergetic formulated diets having grade protein levels. Aquaculture Research, 41, 278-294. 